\section{Six new cases confirm the clinical molecular profile of complete combined $17 \alpha$-hydroxylase/ 17,20-lyase deficiency in Brazil}

\author{
Seis novos casos confirmam o perfil clínico molecular de deficiência \\ combinada de 17 alfa-hidroxilase/17,20-liase no Brasil
}

Daiane Rodrigues Barbosa Belgini', Maricilda Palandi de Mello', Maria Tereza Matias Baptista², Daniel Minutti de Oliveira², Fernanda Canova Denardi ${ }^{2}$, Heraldo Mendes Garmes², Oswaldo da Rocha Grassiotto ${ }^{3}$, Cristina Laguna Benetti Pinto ${ }^{3}$, Antonia Paula Marques-de-Faria ${ }^{4}$, Andréa Trevas Maciel-Guerra ${ }^{4}$, Gil Guerra-Júnior ${ }^{5}$

\section{SUMMARY}

In 2004, Costa-Santos and cols. reported 24 patients from 19 Brazilian families with $17 \alpha$-hydroxylase deficiency and showed that p.W406R and p.R362C corresponded to $50 \%$ and $32 \%$ of CYP17A1 mutant alleles, respectively. The present report describes clinical and molecular data of six patients from three inbred Brazilian families with $17 \alpha$-hydroxlyse deficiency. All patients had hypogonadism, amenorrhea and hypertension at diagnosis. Two sisters were found to be $46, X Y$ with both gonads palpable in the inguinal region. All patients presented hypergonadotrophic hypogonadism, with high levels of ACTH (> $104 \mathrm{ng} / \mathrm{mL}$ ), suppressed plasmatic renin activity, low levels of potassium $(<2.8 \mathrm{mEq} / \mathrm{L})$ and elevated progesterone levels (> $4.4 \mathrm{ng} / \mathrm{mL}$ ). Three of them, including two sisters, were homozygous for p.W406R mutation and the other three (two sisters and one cousin) were homozygous for p.R362C. The finding of p.W406R and p.R362C in the CYP17A1 gene here reported in additional families, confirms them as the most frequent mutations causing complete combined $17 \alpha$-hydroxylase/17,20-lyase deficiency in Brazilian patients. Arq Bras Endocrinol Metab. 2010;54(8):711-6

\section{SUMÁRIO}

Em 2004, segundo Costa-Santos e cols., p.W406R e p.R362C correspondiam a 50\% e $32 \%$ dos alelos mutantes do gene CYP17A1, respectivamente, em 24 pacientes de 19 famílias brasileiras com deficiência da $17 \alpha$-hidroxilase. Apresentamos os dados clínicos e moleculares de seis pacientes de três famílias consanguíneas brasileiras com deficiência da $17 \alpha$-hidroxilase. Todas as pacientes apresentavam hipogonadismo, amenorreia e hipertensão ao diagnóstico. Duas irmãs tinham cariótipo 46,XY, ambas com gônadas palpáveis na região inguinal. Todas tinham hipogonadismo hipergonadotrófico, com nível aumentado de ACTH (> $104 \mathrm{ng} / \mathrm{mL}$ ), atividade de renina plasmática suprimida, baixos níveis de potássio $(<2,8 \mathrm{mEq} / \mathrm{L})$ e progesterona aumentada $(>4,4 \mathrm{ng} / \mathrm{mL})$. Três delas, incluindo duas irmãs, apresentaram homozigose para a mutação p.W406R e as outras três (duas irmãs e uma prima) foram homozigotas para a mutação p.R362C. A recorrência das mutações p.W406R e p.R362C no gene CYP17A1 aqui relatada em famílias adicionais confirma que essas são as mais frequentes causadoras do fenótipo completo da deficiência combinada de 17 $\alpha$-hidroxilase/17,20-liase em pacientes brasileiros. Arq Bras Endocrinol Metab. 2010;54(8):711-6
${ }^{1}$ Center for Molecular Biology and Genetic Engineering (CBMEG), Universidade Estadual de Campinas (Unicamp), Campinas, SP, Brazil ${ }^{2}$ Department of Clinical

Medicine, Faculdade de Ciências Médicas (FCM), Unicamp,

Campinas, SP, Brazil

${ }^{3}$ Department of Tocogynecology,

FCM-Unicamp, Campinas, SP, Brazil

${ }^{4}$ Interdisciplinary Group for the

Study of Sex Determination and Differentiation (GIEDDS) Department of Medical Genetics, FCM-Unicamp, Campinas, SP, Brazil ${ }^{5}$ Interdisciplinary Group for the Study of Sex Determination and Differentiation (GIEDDS), Department of Pediatrics, FCMUnicamp, Campinas, SP, Brazil

Correspondence to:

Gil Guerra-Júnior

Departamento de Pediatria, FCM-Unicamp

13083-887 - Campinas, SP, Brazil gilguer@fcm.unicamp.br

Received on Jul/29/2010 Accepted on Nov/11/2010

\section{INTRODUCTION}

$\mathrm{T}$ The microsomal cytochrome $\mathrm{P} 450 \mathrm{cl} 7$ is a single enzyme with two catalytic functions, $17 \alpha$-hydroxylase and 17,20-lyase, which plays a crucial role in the biosynthesis of cortisol and sex steroids. Deficiency of P450c17 (17OHD) in both the adrenal cortex and gonads results 
in impaired production of cortisol and sex hormones, leading to hypersecretion of ACTH and overproduction of mineralocorticoids $(1,2)$.

P450cl7 is encoded by the CYPI7Al gene (OMIM 609300 ), which is located at $10 \mathrm{q} 24.3$ and contains eight exons (3-5). 17OHD is a rare form of congenital adrenal hyperplasia $(\mathrm{CAH})$ with an estimated incidence of about 1:50,000 newborns (1), which represent $1 \%$ of all cases of CAH. Most reports describe isolated cases in consanguineous families (2), and approximately 50 different mutations in CYPI7Al have been described, although some are more common and reoccur in certain ethnic groups. Most mutations have been seen to cause combined $17 \alpha$-hydroxylase/17,20-lyase enzyme deficiency $(1,2,6-17)$.

Typical features of complete 17OHD include hypertension, hypokalemia, and sexual infantilism in genotypic-phenotypic females, and as incomplete male sex differentiation with ambiguous or female genitalia, and also sexual infantilism in $46, \mathrm{XY}$ subjects $(1,2)$. Nevertheless, there is considerable variation in clinical and biochemical features of 17OHD (18), including the variant of isolated 17,20-lyase deficiency (19). The severity of the clinical disease tends to be milder with mutations that retain partial catalytic activity in assays using heterologous expression systems (1), but the age of hypertension onset, the degree of hypokalemia, and the aldosterone production rate appear to vary, even among patients with mutations that completely inactivate the enzyme (2).

In 2004, Costa-Santos and cols. (9) published clinical and molecular data of 24 patients with 17OHD from 19 kindreds from the Brazilian Congenital Adrenal Hyperplasia Multicenter Study Group and showed seven novel CYP17 mutations. Two of them, p.W406R and p.R362C accounted for $50 \%$ and $32 \%$ of the mutant alleles (9).

We describe here clinical and molecular data of six additional Brazilian patients with 17OHD from three different kindreds.

\section{CASE REPORTS}

Clinical data and blood specimens of the patients and relatives were collected with approval by the appropriate institutional review board and a signed informed consent was obtained.

Tables 1 and 2 show clinical, biochemical and hormonal data from the six patients with $17 \mathrm{OHD}$.

Patient 1 presented at age 15 because of absence of pubertal development signs (failure of breast development, absence of pubic hair and menarche). She had systolic hypertension $(170 / 110 \mathrm{mmHg})$ since she was 14 years old. Her parents were second cousins. She had had four older sisters of unknown genetic sex who died at the ages of 5, 7,9 and 13. The oldest sister, who died in her sleep, was also prepubertal and had hypertension.

Patients 2.1 and 2.2 are siblings born to consanguineous parents (first cousins). They were raised as girls and were examined at 17 and 18 years of age, respectively, because of lack of pubertal development (failure of breast development, absence of pubic hair and menarche). Both had hypertension since they were 12 years old $(170 / 110 \mathrm{mmHg}$ and $180 / 120 \mathrm{mmHg}$, respectively). Patient 2.2 had a stroke with permanent partial right facial paralysis by the time of hypertension diagnosis. They presented prepubertal female external genitalia with bilateral inguinal gonads but no uterus at ultrasound. Their karyotypes were both 46,XY.

Table 1. Clinical and biochemical features of $170 \mathrm{HD}$ patients

\begin{tabular}{|c|c|c|c|c|c|c|c|}
\hline Case & $\begin{array}{l}\text { Age at diagnosis } \\
\text { (yr) }\end{array}$ & Karyotype & $\begin{array}{l}\text { External } \\
\text { genitalia }\end{array}$ & Sex of rearing & BP (mmHg) & $\begin{array}{c}\mathrm{Na} \\
(\mathrm{mEq} / \mathrm{L})\end{array}$ & $\begin{array}{c}\mathrm{K} \\
(\mathrm{mEq} / \mathrm{L})\end{array}$ \\
\hline 1 & 15 & $46, X X$ & $\mathrm{~F}$ & $\mathrm{~F}$ & $170 / 110$ & 142 & 2.5 \\
\hline 2.1 & 17 & $46, X Y$ & $F$ & $\mathrm{~F}$ & $170 / 110$ & 141 & 2.6 \\
\hline 2.2 & 18 & $46, X Y$ & $F$ & $\mathrm{~F}$ & $180 / 120$ & 150 & 2.6 \\
\hline 3.1 & 19 & $46, X X$ & $F$ & $\mathrm{~F}$ & $180 / 110$ & 149 & 2.7 \\
\hline 3.2 & 18 & $46, X X$ & $F$ & $\mathrm{~F}$ & $160 / 100$ & 144 & 2.7 \\
\hline 3.3 & 14 & $46, X X$ & $F$ & $\mathrm{~F}$ & $160 / 100$ & 142 & 2.8 \\
\hline Normal values & & & & & & $136-146$ & $3.5-5.5$ \\
\hline
\end{tabular}


Table 2. Plasma basal hormonal values in $170 \mathrm{HD}$ patients

\begin{tabular}{lccccccc}
\hline & $\mathbf{1}$ & $\mathbf{2 . 1}$ & $\mathbf{2 . 2}$ & $\mathbf{3 . 1}$ & $\mathbf{3 . 2}$ & $\mathbf{3 . 3}$ & $\begin{array}{c}\text { Normal values } \\
\text { (adult female) }\end{array}$ \\
\hline LH (IU/L) & 31.2 & 26.1 & 67.3 & 30.5 & 28.9 & 25.2 & $1.9-12.5$ \\
FSH (IU/L) & 50.0 & 52.5 & 81.7 & 80.6 & 75.7 & 88.2 & $1.5-8.0$ \\
ACTH (pg/mLI) & 185 & 102 & 274 & 309 & 256 & 104 & $<46$ \\
Cortisol ( $\mu \mathrm{g} / \mathrm{dL})$ & 2.4 & 2.2 & 2.6 & 2.8 & 2.6 & 2.6 & $5.0-25.0$ \\
PRA (ng/ml/h) & 0.3 & 05 & 0.3 & 0.3 & 0.4 & 0.3 & $0.1-2.3$ \\
Progesterone (ng/mL) & 4.4 & 5.0 & 4.9 & 4.6 & 6.6 & 8.4 & $0.1-1.4$ \\
17-OHprogesterone $(\mathrm{ng} / \mathrm{mL})$ & 0.3 & 0.5 & 0.2 & 0.6 & 0.3 & 0.2 & $0.2-1.5$ \\
DHEA (ng/mL) & 0.5 & 0.8 & 0.6 & 1.1 & 0.9 & 0.8 & $3.0-6.1$ \\
DHEA-S ( $\mu \mathrm{g} / \mathrm{dl})$ & 50 & 44 & 62 & 55 & 60 & 40 & $80-560$ \\
Androstenedione $(\mathrm{ng} / \mathrm{mL})$ & 0.2 & 0.3 & 0.2 & 0.2 & 0.3 & 0.2 & $0.7-3.6$ \\
Testosterone $(\mathrm{ng} / \mathrm{dL})$ & 0.06 & 0.06 & 0.08 & 0.06 & 0.06 & 0.08 & $0.06-0.85$ \\
\hline
\end{tabular}

Patients 3.1 and 3.2 are siblings born to consanguineous parents (first cousins) (Figure 1). They presented at the age of 18 and 19 because of absence of pubertal development signs (failure of breast development, absence of pubic hair and menarche) and hypertension $(180 / 110 \mathrm{mmHg}$ and $160 / 100 \mathrm{mmHg}$, respectively). They were prepubertal with female external genitalia. Their karyotypes were both 46,XX.

Patient 3.3 is a cousin of 3.1 and 3.2 and was also born to consanguineous parents (first cousins) (Figure 1). She was evaluated at the age of 14 because of delayed puberty (failure of breast development, absence of pubic hair and menarche). Hypertension was noticed during clinical evaluation $(160 / 100 \mathrm{mmHg})$. Physical examination revealed absence of breast development, pubic and axillary hair with normal infantile female external genitalia. Her karyotype was 46,XX.

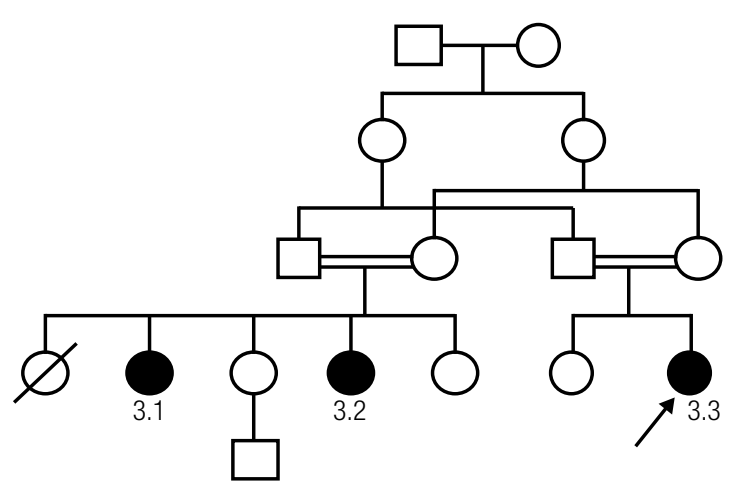

Figure 1. Pedigree of family 3.
Genomic DNA samples were obtained from peripheral blood by Proteinase K digestion and phenol/ chloroform extraction following standard techniques. Primers for PCR amplifying the eight exons including exon-intron junctions of CYPI7Al gene were designed using GeneRunner v3.0 free software. The amplified fragments were purified with Wizard SV Gel and PCR Clean-up System (Promega, Madison, WI, USA) and both sense and antisense DNA strands were directly sequenced with Big Dye Terminator Cycle Sequencing Kit V3.1 Ready Reaction (ABI PRISM/PE Biosystems, Foster City, CA, USA). Sequencing reactions were electrophoresed in a ABI PRISM 3700 Automated DNA Sequencer capillary system according to the manufacturer's recommendations (ABI PRISM/PE Biosystems, Foster City, CA, USA). Sequences obtained were compared to the normal CYP17Al genomic sequence (ENSG00000148795).

Patients 1, 2.1 and 2.2 showed the nucleotide change c.1388 $>\mathrm{C}$ in exon 7 . The three patients were homozygous for the mutation that causes amino acid substitution p.W406R (Figure 2A). The CYPI7Al sequence analysis of patients $3.1,3.2$ and 3.3 revealed a c. $1256 \mathrm{C}>\mathrm{T}$ homozygous transition in codon 362 located in exon 6 . This nucleotide substitution leads to the p.R362C missense mutation (Figure 2B). Patients homozygous for p.R362C mutations were also homozygous for the less frequent allele of the following polymorphisms: rs743572 (5'UTR), rs6162 (exon 1), rs6163 (exon 1), rs743575 (intron 2), rs3740397 (intron 5), rs4919686 (intron 6), rs10883783 (intron 7) and a novel IVS-130del35bp. The deletion of $35 \mathrm{bp}$ in 

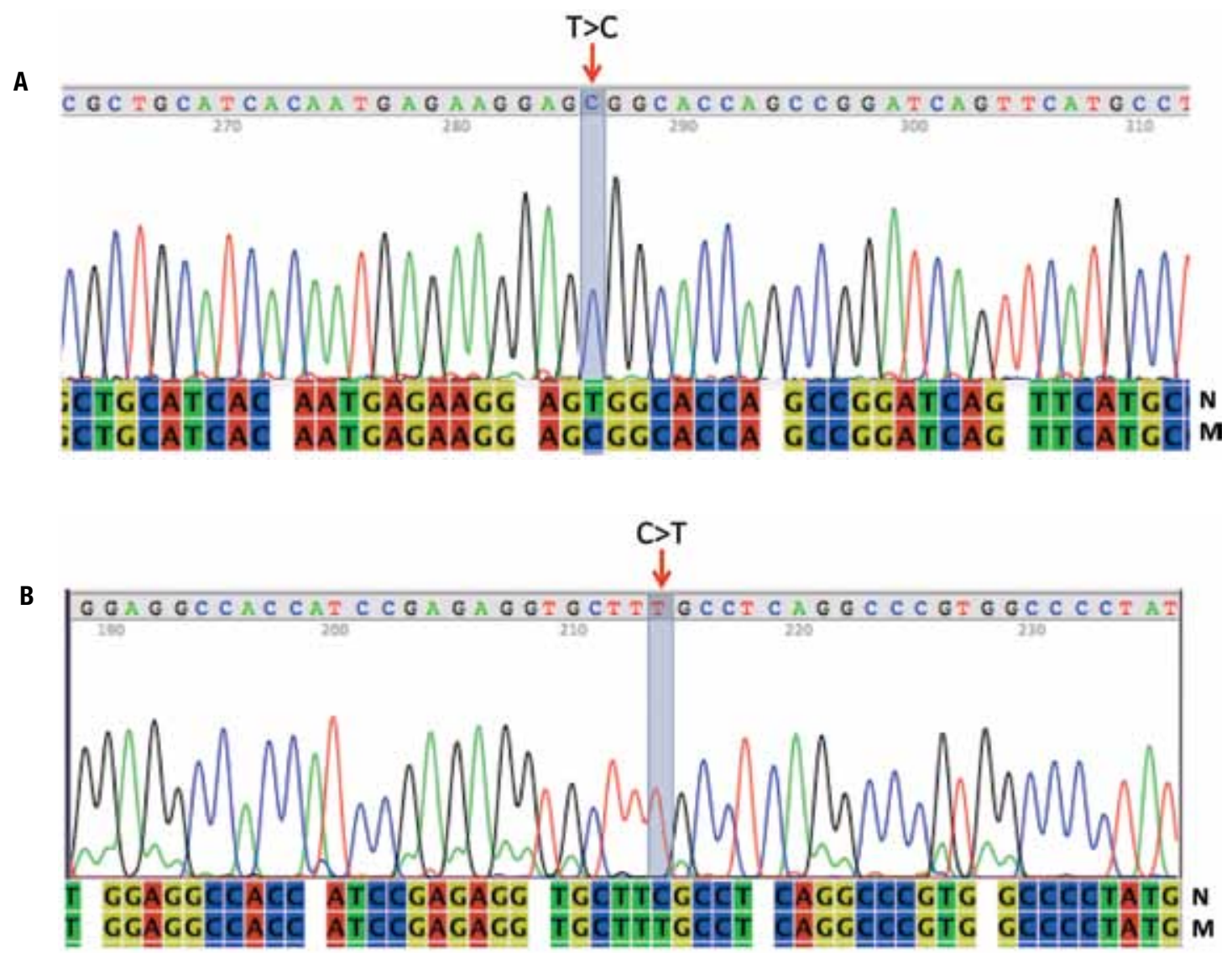

Figure 2. Eletropherograms showing parts of the CYP17A1 gene sequences. A) Exon 7; the arrow denotes the C.1388T>C change causing the p.W406R mutation found in patients 1, 2.1 and 2.2. B) Exon 6; the arrow denotes the C.1256C >T change causing the p.R362C mutation found in patients $3.1,3.2$ and 3.3. $\mathrm{N}=$ normal sequence; $\mathrm{M}=$ mutant sequence.

intron 7 must be a frequent polymorphism in Brazilian population since it was found in $15.6 \%$ control alleles. Unfortunately, DNA samples of their parents were not available for analysis to confirm the segregation of $\mathrm{mu}-$ tations. However, patients have been considered homozygous for either p.W406R or p.R362C mutations without investigating microsatellites heterozygosis due to close consanguinity between parents and also due to the fact that CYPI7Al gene deletions have never been reported.

\section{DISCUSSION}

The possibility of studying the CYP17AI gene of several patients affected by the rare $17 \alpha$-hydroxylase/17,20lyase deficiency is an effective tool to clarify the molecular mechanisms and genetic characteristics of the disease and also to gather more information about the structure-function relationship of this protein. $\mathrm{P} 450 \mathrm{cl} 7 \mathrm{can}$ be considered the qualitative regulator of steroidogen- esis by determining which kind of steroids will be produced: mineralocorticoids in which P450c17 is absent, glucocorticoids when $17 \alpha$-hydroxylation is active, and sex hormones when 17,20-cleavage takes place. Therefore, the knowledge concerning P450cl7 will always be of great impact for understanding hypertension, adrenarche, puberty, and hyperandrogenism, with obvious implications in fertility.

Homozygous carriers of either p.W406R or p.R362C mutations have been described as presenting hypertension, hypokalemia, and sexual infantilism (9); a typical phenotype observed in complete combined 17 $\alpha$-hydroxylase/17,20-lyase deficiency (19). The six patients reported here, who were all born to consanguineous parents, also presented a complete combined $17 \alpha$-hydroxylase/17,20-lyase deficiency phenotype, with moderate to severe hypertension, hypokalemia $(<$ $2.8 \mathrm{mEq} / \mathrm{L}$ ), elevated ACTH (> $104 \mathrm{ng} / \mathrm{mL})$ and progesterone $(>4.4 \mathrm{ng} / \mathrm{mL})$ with low levels of cortisol and $17 \mathrm{OH}$-progesterone, and sexual infantilism (in both 
46,XX and 46,XY subjects) with low levels of DHEA, DHEA-S, androstenedione and testosterone and high levels of LH and FSH. As showed by Martin and cols. (8), our data confirmed the importance of evaluating $\mathrm{LH}, \mathrm{FSH}, \mathrm{ACTH}$, progesterone, and potassium and/or plasmatic renin activity to diagnose complete combined $17 \alpha$-hydroxylase / 17,20-lyase deficiency. A good genotype-phenotype correlation is therefore observed since p.W406R and p.R362C mutations showed no residual enzymatic activity in expression studies using COS-7 or HEK-293 cells and in yeast, indicating that the resulting phenotype for both mutations is the complete combined 17 $\alpha$-hydroxylase/17,20-lyase deficiency (9).

According to Costa-Santos and cols. (9), p.W406R and p.R306C account, respectively, for $50 \%$ and $32 \%$ of CYP17A1 mutant alleles among Brazilian patients. The majority of affected individuals carrying p.W406R or p.R362C mutations are of Spanish or Portuguese descent, respectively (9). In contrast, no other mutation among almost 50 in the CYPI7 gene is related to patients of Spanish or Portuguese origin $(1,2,6,7,10$ 12,14-17). Brazilians form one of the most heterogeneous populations in the world, as the result of more than five centuries of miscegenation from the four continents: America, Europe, Africa, and Asia. When the Portuguese arrived in Brazil in the year 1500, around 2.5 million South American Indians already lived in the country. The initial colonization involved almost exclusively Portuguese men, therefore, the first miscegenation occurred between European men, mainly Portuguese, and native Indian women. Between the years of 1500 and 1800 around half a million Portuguese men arrived in Brazil. Since the middle of the century to 1855 , around four million African slaves came to Brazil. In 1808, Portuguese royalty moved from Portugal to Brazil and opened the ports to all nations. Between 1820 and 1975, around six million immigrants officially arrived in Brazil; 70\% Portuguese and Italians, in equal numbers, followed by the Spanish, Germans, Syrians, Lebanese and Japanese (20). So, it is very difficult to define the correct ancestry of Brazilian patients, but the families included in the present study reported to have Spanish (patients 1, 2.1 and 2.2, all from Lagoa Santa - State of Minas Gerais - Brazil) and Portuguese (patients 3.1, 3.2 and 3.3, all from Jeremoabo - State of Bahia - Brazil) origins, confirming the data of CostaSantos and cols. (9). The homozygosity for the less frequent allele in several polymorphisms found in patients 3.1, 3.2 and 3.3 might also indicate that this mutant allele corresponds to a rare CYPI7AI haplotype introduced in Brazil by Europeans.

In conclusion, we confirm p.W406R and p.R362C mutations as causes of complete combined $17 \alpha$-hydroxylase/17,20-lyase deficiency; a high genotype-phenotype correlation is observed for mutation carriers; and also they are the most frequent mutations in Brazilian patients, specially those with Spanish or Portuguese ancestry.

Acknowledgements: The authors would like to thank Dr. Márcio José da Silva from CBMEG sequencing facility for technical support.

Disclosure: no potential conflict of interest relevant to this article was reported.

\section{REFERENCES}

1. Auchus RJ. The genetics, pathophysiology, and management of human deficiencies of P450c17. Endocrinol Metab Clin N Am. 2001;30:101-19.

2. Yanase T, Simpson ER, Waterman MR. 17-hydroxylase/17,20-lyase deficiency from clinical investigation to molecular definition. Endocr Rev. 1991;12:91-108.

3. Matteson KJ, Picado-Leonard J, Chung BC, Mohandas TK, Miller WL. Assignment of the gene for adrenal P450c17 (steroid 17 alphahydroxylase/17,20-lyase) to human chromosome. J Clin Endocrinol Metab. 1986;63:789-91.

4. Fan YS, Sasi R, Lee C, Winter JS, Waterman MR, Lin CC. Localization of the human CYP17A1 gene (cytochrome P450 (17alpha)) to $10 \mathrm{q} 24.3$ by fluorescence in situ hybridization and simultaneous chromosome banding. Genomics. 1992;14:1110-1.

5. Picado-Leonard J, Miller WL. Cloning and sequence of the human 17 gene for $\mathrm{P} 450 \mathrm{c} 17$ (steroid 17 alpha-hydroxylase/17,20 lyase): similarity with the gene for P450c21. DNA. 1987;6:439-48.

6. Miura K, Yasuda K, Yanase T, Yamakita N, Sasano H, Nawata H, et al. Mutation of cytochrome P-45017 alpha gene (CYP17A1) in a Japanese patient previously reported as having glucocorticoid responsive hyperaldosteronesteronism: with a review of Japanese patients with mutations of CYP17A1. J Clin Endocrinol Metab. 1996;81:3797-801.

7. Hahm JR, Kim DR, Jeong DK, Chung JH, Lee MS, Min YK, et al. A novel compound heterozygous mutation in the CYP17A1 (P450 17alpha-hydroxylase) gene leading to 17alpha-hydroxylase/17,20-lyase deficiency. Metabolism. 2003;52:488-92.

8. Martin RM, Lin CJ, Costa EM, de Oliveira ML, Carrilho A, Villar H, et al. P450c17 deficiency in Brazilian patients: biochemical diagnosis through progesterone levels confirmed by CYP17 genotyping. J Clin Endocrinol Metab. 2003;88:5739-46.

9. Costa-Santos M, Katar CE, Auchus RJ; and Brazilian Congenital Adrenal Hyperplasia Multicenter Study Group. Two prevalent CYP17 mutations and genotype-phenotype correlations in 24 Brazilian patients with 17-hydroxylase deficiency. J Clin Endocrinol Metab. 2004;89:49-60.

10. Patocs A, Liko I, Varga I, Gergics P, Boros A, Futo L, et al. Novel mutation of the CYP17A1 gene in two unrelated patients with combined 17alphahydroxylase/17,20-lyase deficiency: demonstration of absent enzyme activity by expressing the mutant CYP17A1 gene and by three-dimensional modeling. J Steroid Biochem Mol Biol. 2005;97:257-65. 
11. Yang J, Cui B, Sun S, Shi T, Zheng S, Bi Y, et al. Phenotype-genotype correlation in eight Chinese 17 $\alpha$ hydroxylase/17,20-lyase deficiency patients with five novel mutations of CYP17A1 gene. J Clin Endocrinol Metab. 2006;91:3619-25.

12. Rosa S, Duff C, Meyer M, Lang-Muritano M, Balercia G, Boscaro $M$, et al. P450c17 deficiency: clinical and molecular characterization of six patients. J Clin Endocrinol Metab. 2007;92:1000-7.

13. Martin RM, Oliveira PSL, Costa EMF, Arnhold IJP, Mendonça BB. Combined 17 alpha-hydroxylase/17,20-lyase deficiency due to a homozygous 25 BP duplication (NT 4157-4181) at exon 5 in CYP17 resulting in a premature stop codon predicated by molecular modeling. Arq Bras Endocriol Metab. 2008;52:1317-20.

14. Qiao J, Chent X, Zuo C-L, Gu Y-Y, Liu B-L, Liang J, et al. Identification of steroid biosynthetic defects in genotype-proven heterozygous individuals for $17 \alpha$-hydroxylase/17-20-lyase deficiency. Clin Endocrinol. 2010;72:312-9.

15. Nuzzo V, Tauchmanova L, Brunetti-Pierri R, Zuccoli A, Lupoli G, Colao $\mathrm{A}$, et al. $\mathrm{A}$ novel mutation in the $\mathrm{N}$-terminal region of the
CYP17A1 gene in a patient with 17 alpha-hydroxylase/17,20-lyase deficiency. J Endocrinol Invest. 2009;32:322-4.

16. Rosa S, Steigert M, Lang-Muritano M, I'Allemand D, Schoenle EJ, Biason-Lauber A. Clinical, genetic and functional characteristics of three novel CYP17A1 mutations causing combined 17alpha-hydroxylase/17,20-lyase deficiency. Horm Res Paediatr. 2010;73:198-204.

17. Katsumata N, Ogawa E, Fujiwara I, Fujikura K. Novel CYP17A1 mutation in a Japanese patient with combined 17alpha-hydroxylase/17,20-lyase deficiency. Metabolism. 2010;59:275-8.

18. Kater CE, Biglieri EG. Disorders of steroid 17 $\alpha$-hydroxylase deficiency. Endocrinol Metab Clin North Am. 1994;23:341-57.

19. Geller DH, Auchus RJ, Mendonça BB, Miller WL. The genetic and functional basis of isolated 17,20 lyase deficiency. Nat Genet. 1997;17:201-5.

20. IBGE - Instituto Brasileiro de Geografia e Estatística 2000 Brasil: 500 anos de povoamento. Available at: http://www.ibge.gov.br/ brasil500. Accessed on: 17 Jul 2010. 